\title{
EFFECT OF BENZYLADENINE AND CHEMICAL FERTILIZATION ON GROWTH, FLOWERING AND CHEMICAL COMPOSITION OF JASMINUM SAMBAC PLANT
}

\author{
Eman M. Abou El-Ghait*, A.S.M. Youssef*, Y.F. Mohamed*, T.M. Noor El-Deen ${ }^{* *}$ and \\ Heba I. Mohamed** \\ * Hort. Dept., Fac. Agric., Moshtohor, Benha University, Egypt \\ ** Ornamental Plants \& Landscape Gardening Res. Dept., Hort. Res. Inst., ARC, Egypt
}

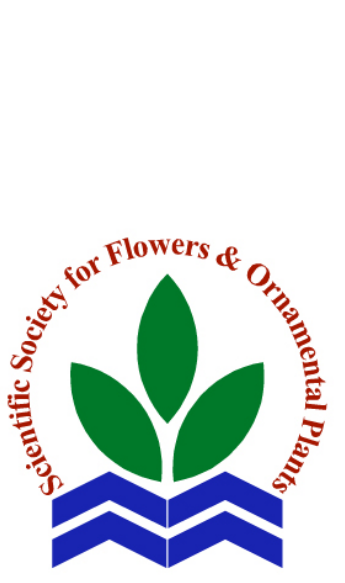

Scientific J. Flowers \& Ornamental Plants, 7(4):379-391 (2020).

Received: 28/6/2020

Accepted: $22 / 7 / 2020$

ABSTRACT: A pot experimental study was carried out at the Floriculture Nursery of the Horticulture Department, Faculty of Agriculture at Moshtohor, Benha University, Egypt during 2017 and 2018 seasons to study the effect of 16 treatments represented the combination between foliar spraying with four benzyladenine (BA) concentrations $(0.0,20,40$ and $60 \mathrm{ppm})$ and four chemical fertilization rates $(0.0,2,4$ and $6 \mathrm{~g} \mathrm{NPK/pot)}$ on the growth, flowering and chemical composition of Arabian jasmine plant (Jasminum sambac Ait). The obtained results cleared that the tallest plants, the highest number of branches and leaves, the heaviest leaves fresh weight/plant, the highest number of flowers/plant, the heaviest flowers fresh weight/plant, the highest number and length of roots/plant, the heaviest fresh weight of roots/plant as well as the richest leaf total carbohydrates, nitrogen, phosphorus and potassium percentages were obtained by those treated with BA at $60 \mathrm{ppm}+$ chemical fertilization at $6 \mathrm{~g} /$ pot in the two seasons. Conclusively, spraying jasmine plants with BA at $60 \mathrm{ppm}$ and supplying the plants with NPK mineral fertilizer at 6 g/pot, induced prospective effects on vegetative growth and flowering parameters with higher quality of this plant.

Key words: Arabian jasmine, Jasminum sambac, benzyladenine, chemical fertilization, growth, flowering and chemical constituents.

\section{INTRODUCTION}

Jasminum (Fam: Oleraceae) is a genus of 200 or more species of deciduous, evergreen shrubs and climbers native to Tropical Asia and Africa. J. sambac (Arabian jasmine, pikake) is an evergreen, twining climber or scrambler with angular stems and bushy growth, reaches to 2-3 m height. Lustrous, dark green leaves, some in whorls of 3 , others opposite, are reduced to one broadly ovate leaflet, to $8 \mathrm{~cm}$ long. Bears small cymes of 3-12 salver form, strongly scented white flowers, $2.5 \mathrm{~cm}$ across, fading to pink, mainly in summer, but often irregularly throughout the year
(Brickell, 1997). It is cultivated for commercial as a source of perfumes, and ornamentals, nice smell in the garden. In China the flowers are used for perfuming tea, while in India they are made into garlands (Heneidy, 2010).

Many authors demonstrated that growth and flowering of many ornamental plants are greatly influenced by different growth regulators among which kinins group. Benzyladenine (BA) is recognized by its ability to induce cell division in certain plant tissues (Cheema and Sharma, 1982) it can also overcome the apical dominance of many plants and stimulate the lateral buds to 
develop into an entire new plant. BA can delay senescence and cause transport of many solutes from older parts of the leaves or even from older leaves into the treated zone (Salisbury and Ross, 1974). In this respect, the beneficial role of BA was reported by many authors e.g. Youssef (2004) on Pelargonium graveolens, Currey and Erwin (2012) on 11 Kalanchoe species, Carey et al. (2013) on Salvia nemorosa (L.) "Caradonna”, Tandel et al. (2018) on Adhatoda zeylanica, Singh and Bala (2018) on chrysanthemum. Additionally, Youssef and Mady (2013) cleared that spraying Aspidistra elatior plants with BA at $75 \mathrm{ppm}$ improved all tested vegetative and chemical constituents of this plants. Moreover, Abd Al Lateef and Hade (2018) showed that spraying Viola tricolor plants with BA at 30 ppm enhanced all vegetative and flowering traits.

Most plants need more than two applications of fertilizers during the growing season. Thus, fertilization must continue for good vegetative growth to produce a good flower and large new mature bulbs (Rees, 1992). For natural plants to grow and thrive they need a number of chemical elements, but the most important are nitrogen, phosphorus and potassium. Most packaged fertilizers contain these three macronutrients. Nitrogen is especially important, and every amino acid in plants contains nitrogen as an essential component for plants to manufacture new cells (Marschner, 1997). Phosphorus which has been called the key to life is essential for cell division and for development of meristematic tissues and it is very important for carbohydrate transformation due to multitude of phosphorylation reaction and to energy rich phosphate bond (Lambers et al., 2008). Potassium is important for growth and elongation probably due to its function as an osmoticum and may react synergistically with IAA. Moreover, it promotes $\mathrm{CO}_{2}$ assimilation and translocation of carbohydrates from the leaves to storage tissues (Mengel and Kirkby, 1987). In this concern, Mostafa (2018) revealed that spraying areca palm plants with chemical fertilizer at $6 \mathrm{~g} /$ pot produced the highest plant height, stem diameter, stem length, number of leaves/plant and fresh, dry weights of leaf of this plant

Thereupon, this study was undertaken to evaluate the effect of benzyladenine (BA) and mineral fertilization (NPK) on growth, flowering and chemical composition of Jasminum sambac plant.

\section{MATERIALS AND METHODS}

A pot experimental study was conducted at the Floriculture Nursery of the Horticulture Department, Faculty of Agriculture at Moshtohor, Benha University, during 2017 and 2018 seasons to study the ability of benzyladenine (BA) treatments $(0$, 20, 40 and $60 \mathrm{ppm}$ ) and some chemical fertilization treatments $(0,2,4$ and 6 g/plant) in combining treatments to lump their benefits in producing high quality flowers of Jasminum sambac Ait. plants.

\section{Plant material:}

Arabian jasmine (Jasminum sambac Ait.) plants were used for the present study, for this purpose well established three months old healthy and uniform sized plants having 7-8 leaves and 13-15 cm height were selected for conducting this study. The seedlings were obtained from Floriculture Nursery of the Horticulture Department, Faculty of Agriculture at Moshtohor, Benha University. The plants were repotted in plastic pots of $25 \mathrm{~cm}$ diameter (one plant/pot) packed with planting media, containing clay + compost + sand at $1: 1: 1$ by volume, and placed in a partial shade (15000-17000 lux) under lath house condition on March, $1^{\text {st }}$ for the two seasons of this study. Mechanical and chemical analysis of the used medium are shown in Tables (a and b).

\section{Procedure and lay-out of the experiment:}

Two factors were involved in the present study, the first was BA treatments and the second was chemical fertilization. The layout of the experiment was designed to provide a 
Table a. Mechanical analysis of the experimental soil.

\begin{tabular}{lccc}
\hline Parameters & Unit & $\mathbf{2 0 1 7}$ & Seasons \\
\hline Coarse sand & $\%$ & 11.23 & $\mathbf{2 0 1 8}$ \\
Fine sand & $\%$ & 34.51 & 12.18 \\
Silt & $\%$ & 15.36 & 35.82 \\
Clay & $\%$ & 38.90 & 13.41 \\
Textural class & - & Sandy loam & 38.59 \\
\hline
\end{tabular}

Table b. Chemical analysis of the experimental soil.

\begin{tabular}{lccc}
\hline Parameters & Unit & $\mathbf{2 0 1 7}$ & Seasons \\
\hline CaCO $_{3}$ & $\%$ & 1.21 & $\mathbf{2 0 1 8}$ \\
Organic matter & $\%$ & 1.78 & 1.35 \\
Available nitrogen & $\%$ & 0.92 & 1.89 \\
Available phosphorus & $\%$ & 0.39 & 0.94 \\
Available potassium & $\%$ & 0.86 & 0.41 \\
E.C & $\mathrm{ds} / \mathrm{m}$ & 1.35 & 0.82 \\
pH & - & 7.32 & 1.39 \\
\hline
\end{tabular}

factorial experiment in randomized complete blocks. The study contained 16 treatments (4 concentration of BA treatments $\times 4$ rates of chemical fertilization) with three replicates. Each replicate contained 4 pots.

\section{Plant growth regulators treatments:}

Jasmine plants were subjected to foliar spray with BA at 0.0, 20, 40 and $60 \mathrm{ppm}$ six times at two weeks interval, starting after one month from repotting in the two seasons of this study.

\section{Fertilization treatments:}

Jasmine plants received chemical fertilizer by using ammonium nitrate (33\% $\mathrm{N})$, calcium superphosphate $\left(15.5 \% \quad \mathrm{P}_{2} \mathrm{O}_{5}\right)$ and potassium sulfate $\left(48 \% \mathrm{~K}_{2} \mathrm{O}\right)$. A mixture of the three fertilizers, with a ratio of $1: 1: 1$ ( $\mathrm{N}: \mathrm{P}_{2} \mathrm{O} 5: \mathrm{K}_{2} \mathrm{O}$ ), was prepared and applied to the plants at the rate of 2, 4 and $6 \mathrm{~g} /$ pot as top dressing six times at monthly interval, starting after one month from planting time in the two seasons of this study. Common agricultural practices (irrigation, manual weed control, ... etc.) were conducted when needed.

\section{Recorded data:}

At the end of this study (end of December during the two seasons) the following data were recorded:
1. Vegetative growth parameters: plant height $(\mathrm{cm})$, number of branches/plant, number of leaves/plant, fresh weight of leaves/plant (g) and dry weight of leaves/plant (g).

2. Flowering growth parameters: number of flowers/plant and fresh weight of flowers/plant (g).

3. Root growth parameters: number of roots/plant, root length/plant $(\mathrm{cm})$ and fresh weight of roots/plant (g).

4. Chemical composition determination: total nitrogen percentage was determined in the dried leaves by using the modified microkjeldahl method as described by Pregl (1945), phosphorus was determined colourimetrically in a spectronic (20) spectrophotometer using the method described by Trouge and Meyer (1939), potassium content was determined by a flame photometer according to Brown and Lilleland (1946) and total carbohydrates content was determined in dried leaf powder according to Herbert et al. (1971).

\section{Statistical analysis:}

All obtained data in both seasons of study were subjected to analysis of variance as factorial experiments in a complete randomized block design. L.S.D. method was used to differentiate between means according to Snedecor and Cochran (1989). 


\section{RESULTS AND DISCUSSION}

\section{Vegetative growth parameters:}

\section{Plant height:}

Table (1) shows that all tested concentrations of BA succeeded in increasing plant height of Jasminum sambac plants as compared with un-sprayed plants in both seasons. In this respect, the highest concentration $(60 \mathrm{ppm})$ gave the highest values in this concern, followed by the medium concentration (40 ppm) in both seasons. On the other hand, there was a positive correlation between the plant height values and fertilization levels, so the values of plant height increased as the level of fertilization increased to reach the maximum increasing at the highest level (6 g/ plant). This trend was true in both seasons.

Moreover, data presented in Table (1) indicate that all the interactions between BA concentrations and fertilization levels significantly increased plant height of Arabian jasmine plants as compared with untreated plants in both seasons. However, the tallest plants $(43.4$ and $47.8 \mathrm{~cm}$ ) were recorded by 60 ppm BA combined with NPK fertilization at $6 \mathrm{~g} /$ plant treatment in the first and second seasons, respectively.

\section{Number of branches/plant:}

As presented in Table (1), all studied BA and NPK fertilization treatments as well as their interactions increased the number of branches/plant in both seasons. In this concern, the increment in number of branches were in parallel to applied concentration of BA and fertilization levels, so the highest concentration of $\mathrm{BA}$ or the highest level of fertilization significantly scored the highest number of branches/plant when compared with control in both seasons. However, the highest number of branches/plant (8.91 and 8.43) was recorded by $60 \mathrm{ppm}$ BA-sprayed plants combined with NPK fertilization at $6 \mathrm{~g} /$ plant in the first and second seasons, respectively.

\section{Number of leaves/plant:}

Data presented in Table (2) cleared that using BA at 60 ppm was more effective in

Table 1. Effect of benzyladenine (BA) and fertilization treatments on plant height (cm) and number of branches/plant of Jasminum sambac during 2017 and 2018 seasons.

\begin{tabular}{|c|c|c|c|c|c|c|c|c|c|c|}
\hline \multirow{3}{*}{ BA concentration } & \multicolumn{5}{|c|}{ Plant height (cm) } & \multicolumn{5}{|c|}{ Branches number/plant } \\
\hline & \multicolumn{10}{|c|}{ Fertilization treatments (g/plant) } \\
\hline & $\mathbf{0}$ & 2 & 4 & 6 & Mean & $\mathbf{0}$ & 2 & 4 & 6 & Mean \\
\hline & \multicolumn{10}{|c|}{$1^{\text {st }}$ season } \\
\hline 0.0 & 31.7 & 32.4 & 34.8 & 35.2 & 33.5 & 4.92 & 5.36 & 5.62 & 5.71 & 5.40 \\
\hline 20 ppm & 32.7 & 35.1 & 38.2 & 33.8 & 34.9 & 5.68 & 6.14 & 6.82 & 6.94 & 6.39 \\
\hline $40 \mathrm{ppm}$ & 34.8 & 36.7 & 39.2 & 32.1 & 35.7 & 7.14 & 7.42 & 7.94 & 8.04 & 7.64 \\
\hline $60 \mathrm{ppm}$ & 36.1 & 38.9 & 42.3 & 43.4 & 40.2 & 8.37 & 8.49 & 8.72 & 8.91 & 8.62 \\
\hline Mean & 33.8 & 35.8 & 38.6 & 36.1 & & 6.53 & 6.85 & 7.28 & 7.40 & \\
\hline \multicolumn{6}{|c|}{$\begin{array}{r}\text { L.S.D. at } \mathbf{0 . 0 5} \text { for } \mathrm{BA}=1.24 \\
\text { Fertilization= } 1.24 \\
\text { Interaction }=2.48\end{array}$} & \multicolumn{4}{|c|}{$\begin{array}{l}\mathrm{BA}=0.34 \\
\text { Fertilization }=0.34 \\
\text { Interaction }=0.68\end{array}$} & \\
\hline & \multicolumn{10}{|c|}{$2^{\text {nd }}$ season } \\
\hline 0.0 & 32.6 & 34.7 & 38.2 & 39.4 & 36.2 & 4.76 & 5.08 & 5.39 & 5.41 & 5.16 \\
\hline $20 \mathrm{ppm}$ & 34.2 & 38.7 & 42.1 & 43.2 & 39.6 & 5.82 & 6.14 & 6.52 & 6.63 & 6.28 \\
\hline $40 \mathrm{ppm}$ & 35.8 & 33.2 & 45.3 & 46.2 & 40.1 & 7.18 & 7.30 & 7.82 & 7.91 & 7.55 \\
\hline $60 \mathrm{ppm}$ & 33.8 & 41.5 & 46.1 & 47.8 & 42.3 & 8.04 & 8.19 & 8.38 & 8.43 & 8.26 \\
\hline Mean & 34.1 & 37.0 & 42.9 & 44.2 & & 6.45 & 6.68 & 7.03 & 7.09 & \\
\hline \multicolumn{6}{|c|}{$\begin{aligned} \text { L.S.D. at } \mathbf{0 . 0 5} \text { for } & \mathrm{BA}=2.14 \\
& \text { Fertilization }=2.14 \\
& \text { Interaction }=4.28\end{aligned}$} & \multicolumn{5}{|c|}{$\begin{array}{l}\mathrm{BA}=0.41 \\
\text { Fertilization }=0.41 \\
\text { Interaction }=0.82\end{array}$} \\
\hline
\end{tabular}


Table 3. Efect of benzyladenine (BA) and fertilization treatments on dry weight of leaves (g)/plant and number of flowers/plant of Jasminum sambac during 2017 and 2018 seasons.

\begin{tabular}{|c|c|c|c|c|c|c|c|c|c|c|}
\hline \multirow{3}{*}{ BA concentration } & \multicolumn{5}{|c|}{ Dry weight of leaves (g)/plant } & \multicolumn{5}{|c|}{ Number of flowers/plant } \\
\hline & \multirow[b]{2}{*}{0} & \multirow[b]{2}{*}{2} & \multicolumn{6}{|c|}{ Fertilization treatments (g/plant) } & \multirow{3}{*}{6} & \multirow[b]{2}{*}{ Mean } \\
\hline & & & 4 & 6 & Mean & $\mathbf{0}$ & 2 & 4 & & \\
\hline & \multicolumn{9}{|c|}{$1^{\text {st }}$ season } & \\
\hline $\mathbf{0 . 0}$ & 7.36 & 7.81 & 10.72 & 8.74 & 8.66 & 43.8 & 45.1 & 49.3 & 51.2 & 47.4 \\
\hline 20 ppm & 8.81 & 9.12 & 9.67 & 9.84 & 9.36 & 53.7 & 56.2 & 61.2 & 61.9 & 58.3 \\
\hline $40 \mathrm{ppm}$ & 10.11 & 10.61 & 10.69 & 11.32 & 10.68 & 62.4 & 65.0 & 68.3 & 69.2 & 66.2 \\
\hline $60 \mathrm{ppm}$ & 11.12 & 11.32 & 11.78 & 11.86 & 11.52 & 68.7 & 72.1 & 76.4 & 78.1 & 73.8 \\
\hline Mean & 9.35 & 9.72 & 10.72 & 10.44 & & 57.2 & 59.6 & 63.8 & 65.1 & \\
\hline \multirow{3}{*}{\multicolumn{5}{|c|}{$\begin{array}{l}\text { L.S.D. at } \mathbf{0 . 0 5} \text { for } \mathrm{BA}=0.82 \\
\qquad \begin{array}{l}\text { Fertilization }=0.82 \\
\text { Interaction }=1.64\end{array}\end{array}$}} & \multirow{3}{*}{\multicolumn{4}{|c|}{$\begin{array}{l}\mathrm{BA}=4.02 \\
\text { Fertilization }=4.02 \\
\text { Interaction }=8.04\end{array}$}} & & \\
\hline & & & & & & & & & & \\
\hline & & & & & & & & & & \\
\hline & \multicolumn{10}{|c|}{$2^{\text {nd }}$ season } \\
\hline 0.0 & 8.97 & 9.65 & 10.36 & 10.57 & 9.89 & 46.1 & 48.3 & 52.0 & 53.2 & 49.9 \\
\hline $20 \mathrm{ppn}$ & 11.00 & 11.11 & 11.48 & 11.56 & 11.29 & 54.6 & 56.2 & 59.4 & 61.3 & 57.9 \\
\hline $40 \mathrm{ppm}$ & 11.74 & 11.99 & 12.57 & 12.77 & 12.27 & 64.2 & 66.3 & 69.8 & 71.8 & 68.0 \\
\hline 60 ppm & 13.37 & 13.71 & 14.32 & 14.71 & 14.3 & 71.4 & 73.2 & 76.2 & 78.1 & 74.7 \\
\hline Mean & 11.27 & 11.62 & 12.18 & 12.40 & & 59.1 & 61.0 & 64.35 & 66.1 & \\
\hline \multirow{3}{*}{\multicolumn{5}{|c|}{$\begin{array}{l}\text { L.S.D. at } \mathbf{0 . 0 5} \text { for } \mathrm{BA}=1.25 \\
\qquad \begin{array}{l}\text { Fertilization }=1.25 \\
\text { Interaction }=2.50\end{array}\end{array}$}} & \multirow{3}{*}{\multicolumn{4}{|c|}{$\begin{array}{l}\mathrm{BA}=4.19 \\
\text { Fertilization }=4.19 \\
\text { Interaction }=8.38\end{array}$}} & & \\
\hline & & & & & & & & & & \\
\hline & & & & & & & & & & \\
\hline
\end{tabular}

Moreover, Abd Al Lateef and Hade (2018) showed that spraying Viola tricolor plants with BA at $30 \mathrm{ppm}$ enhanced all studied vegetative traits.

The obtained results might be due to the role of benzyladenine on promoting protein synthesis, increasing cell division and enlargement (Cheema and Sharma, 1982). Moreover, these results might be explained according to the role of benzyladenine on promoting proteins, soluble and non-soluble sugars synthesis, or may be due to the ability of benzyladenine for making the treated area to act as a sink in which nutrients from other parts of the plant are drawn (Salisbury and Ross, 1974).

The results respecting chemical fertilization are in conformity with those reported by Hunmili and Paswan (2003) on gerbera, El-Malt et al. (2006) on Hippeastrum vittatum, Youssef and Gomaa (2007) on Iris tingitana, Abou El-Ella (2007) on Acanthus mollis, Kolodziej (2007) on goldenrod, Biswas and Parya (2008) on Solidago canadensis, Nath et al. (2008) on
Peperomia, El-Naggar and El-Nasharty (2009) on Hippeastrum vittatum, Hussein (2009) on Cryptostegia grandiflora and Abd El-All (2011) on Aspidistra elatior.

\section{Flowering growth parameters:}

\section{Number of flowers/plant:}

It is clear from data presented in Table (3) that using the high concentration of BA was more effective in increasing number of flowers/plant as it gave 73.8 and 74.7 , followed by using the medium concentration which recorded 66.2 and 68.0 flowers per plant, with significant differences between themselves in the first and second seasons, respectively. Also, data in the same Table revealed that there were positive relationships between the values of flower number and the used rates of chemical fertilization, hence as the chemical fertilization rates increased the values of flower number increased to reach the greatest increment at $6 \mathrm{~g} /$ pot-fertilized plants as it gave 65.1 and 66.1 flowers per plant in the first and second seasons, respectively. 
As for the interaction effect between BA and chemical fertilization, data presented in Table (3) showed that sprayed jasmine plants with BA at $60 \mathrm{ppm}$ and supplemented with chemical fertilizer at $6 \mathrm{~g} / \mathrm{pot}$ is being the most effective one for producing the highest number of flowers per plant (78.1 and 78.1) in the first and second seasons, respectively.

\section{Fresh weight of flowers/plant (g):}

Data presented in Table (4) showed that the heaviest fresh weight of flowers per plant was recorded by using the high concentration of BA as it scored 33.8 and 41.9 g/plant, followed in a descending order by the medium concentration which scored 29.7 and $37.8 \mathrm{~g} /$ plant in the first and second seasons, respectively. Moreover, all tested rates of chemical fertilization increased this character, especially the high rate as it scored 28.7 and $36.3 \mathrm{~g} /$ plant when compared with un-fertilized plants in the two seasons. As for the interaction effect between BA and chemical fertilization, data in the same Table, showed that all resulted interactions increased the fresh weight of flowers in the two seasons. However, the heaviest flowers fresh weight (35.8 and 43.9 g) was obtained by those received $\mathrm{BA}$ at $60 \mathrm{ppm}$ and fertilized with chemical fertilization at 6 $\mathrm{g} / \mathrm{pot}$, in the first and second seasons, respectively.

The abovementioned results regarding the effect of BA was reported by many authors e.g. Carey et al. (2013) on Salvia nemorosa (L.) "Caradonna" and Singh and Bala (2018) on chrysanthemum. Moreover, Abd Al Lateef and Hade (2018) showed that spraying Viola tricolor plants with BA at 30 ppm enhanced all studied flowering traits.

The results of chemical fertilization are in harmony with those attained by El-Malt et al. (2006) on Hippeastrum vittatum, Youssef and Gomaa (2007) on Iris tingitana, Abou El-Ella (2007) on Acanthus mollis, ElNaggar and El-Nasharty (2009) on Hippeastrum vittatum, Hussein (2009) on Cryptostegia grandiflora and Abd El-All (2011) on Aspidistra elatior.

\section{Root growth parameters:}

\section{Number of roots/plant:}

Data presented in Table (4) revealed that 60 ppm BA-sprayed plants was more promising in increasing the root number of jasmine plant as it scored 18.3 and 21.8 roots/plant, followed by using the medium concentration which scored 16.0 and 20.0 roots/plant, with significant differences between themselves in the first and second seasons, respectively. In addition, there were positive relationships between the rates of chemical fertilization and the values of root number of jasmine plants, whereas the rates of chemical fertilization were increased the values of root number increased till reached the highest rate in the two seasons. With regard to the interaction between chemical fertilization and BA data in the same Table referred that all combinations of chemical fertilization increased number of roots/plant when compared with the combination of control plants in the two seasons. However, the combination of chemical fertilization at 6 $\mathrm{g} /$ pot proved to be the most pronounced one for inducing the highest values, particularly those received BA at $60 \mathrm{ppm}$ as it registered 19.4 and 23.2 roots/plant in the first and second seasons, respectively.

\section{Root length (cm):}

Using the high concentration of BA was more effective on increasing the root length per plant $(47.3$ and $48.4 \mathrm{~cm})$, followed by the medium concentration which scored 44.0 and $44.7 \mathrm{~cm}$, with significant differences between them in the first and second seasons, respectively (Table, 5).

Referring to the effect of chemical fertilization data presented in Table (5) indicated the all tested rates of chemical fertilization increased root length/plant with superiority for the highest rate $(6 \mathrm{~g} / \mathrm{pot})$ as it scored 44.4 and $32.3 \mathrm{~cm}$, in the first and second seasons, respectively. As for the interaction effect between BA and chemical fertilization data presented in Table (5) showed that the combination of BA at the high concentration showed to be the most effective one for producing the 
Table 4. Effect of benzyladenine (BA) and fertilization treatments on fresh weight of flowers (g)/plant and number of roots/plant of Jasminum sambac during 2017 and 2018 seasons.

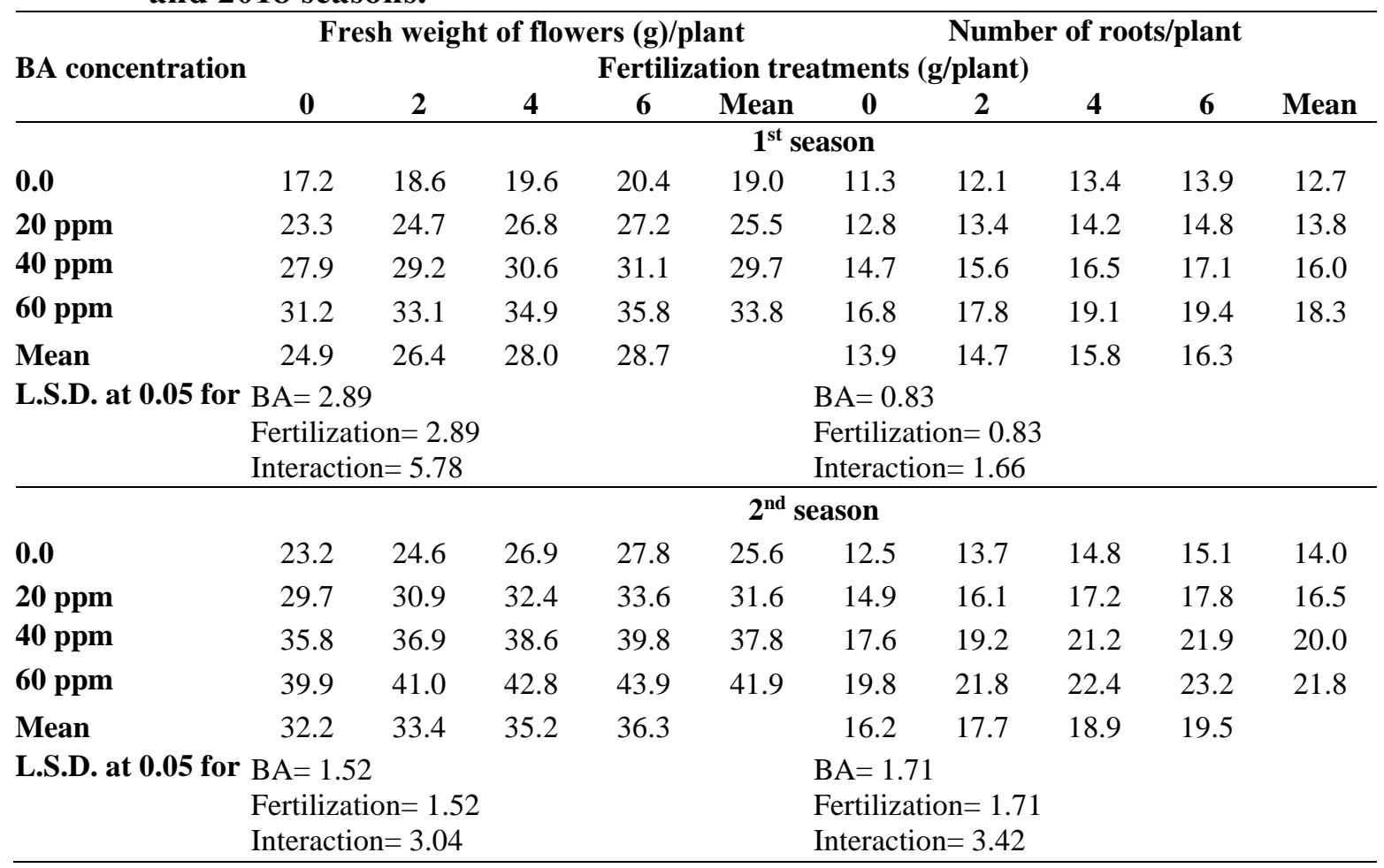

Table 5. Effect of benzyladenine (BA) and fertilization treatments on root length $(\mathrm{cm})$ and fresh weight of roots (g)/plant of Jasminum sambac during 2017 and 2018 seasons.

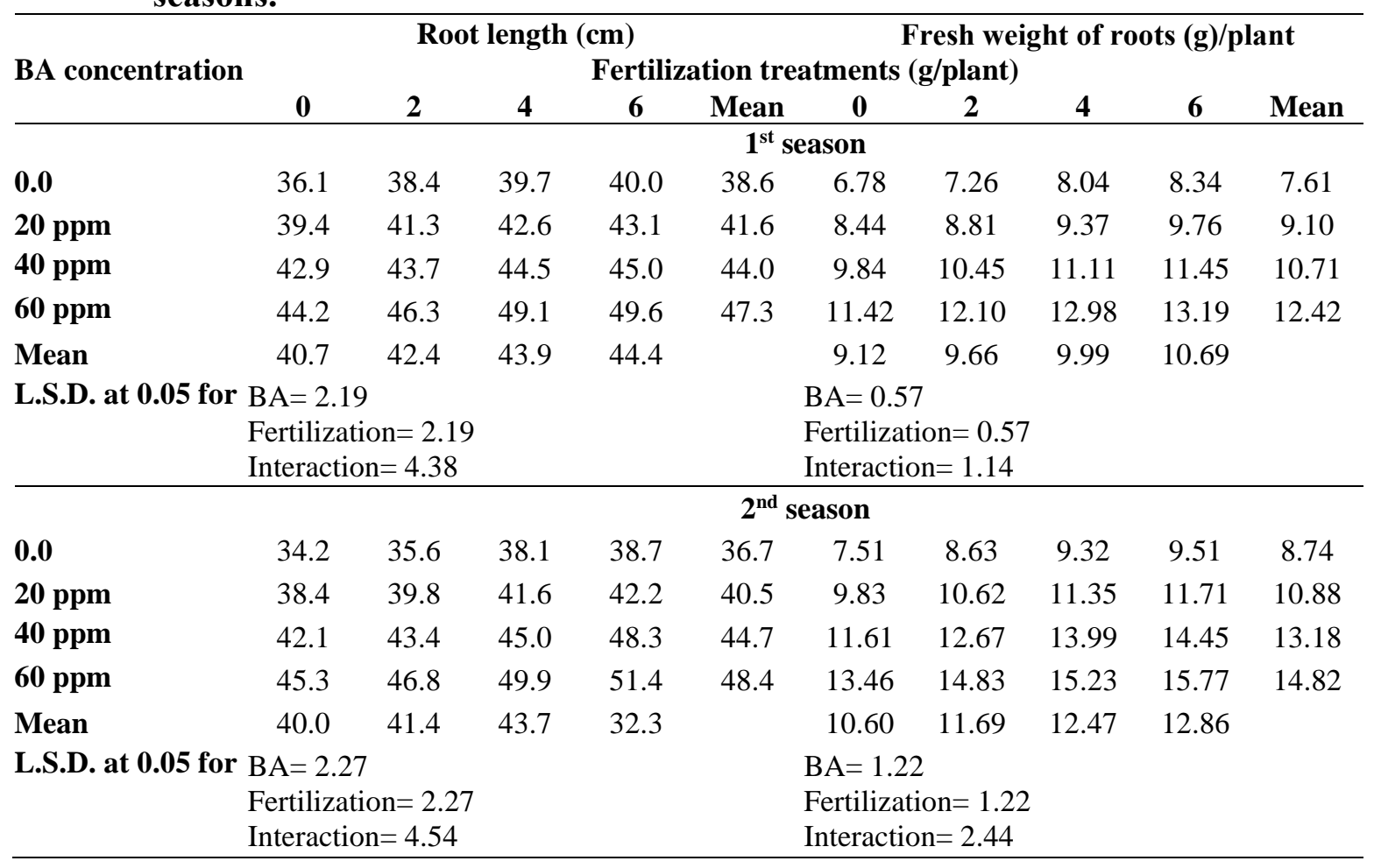


highest values in this concern, especially those fertilized with chemical fertilization at the high level as it recorded 49.6 and 51.4 $\mathrm{cm}$, in the first and second seasons respectively.

\section{Fresh weight of roots/plant (g):}

Data presented in Table (5) indicated that the heaviest fresh weight of roots was recorded by using BA at $60 \mathrm{ppm}$, followed in a descending order by $\mathrm{BA}$ at $40 \mathrm{ppm}$ in the two seasons. However, the lowest fresh weight of roots was gained by un-treated plants, followed in an ascending order by using BA at $20 \mathrm{ppm}$ in the two seasons. Moreover, roots fresh weight of jasmine plants was increased by increasing chemical fertilization rates in the two seasons. In general, all resulted combinations between BA and chemical fertilization increased the fresh weight of roots/plant with significant differences in most cases when compared with un-fertilized plants in the two seasons of this study. However, the heaviest fresh weight of roots/plant was obtained by those sprayed with BA at $60 \mathrm{ppm}$ and fertilized with chemical fertilization at $6 \mathrm{~g} /$ pot in the two seasons.

The aforementioned results regarding chemical fertilization are in conformity with those reported by Hunmili and Paswan (2003) on gerbera, El-Malt et al. (2006) on Hippeastrum vittatum, Youssef and Gomaa (2007) on Iris tingitana, Abou El-Ella (2007) on Acanthus mollis, Kolodziej (2007) on goldenrod, Biswas and Parya (2008) on Solidago canadensis, Nath et al. (2008) on peperomia, El-Naggar and El-Nasharty (2009) on Hippeastrum vittatum, Hussein (2009) on Cryptostegia grandiflora and Abd El-All (2011) on Aspidistra elatior.

\section{Chemical composition determinations:}

\section{Leaf total carbohydrates \%:}

Data presented in Table (6) showed that $\mathrm{BA}$ at the high concentration was more effective on increasing leaf total carbohydrates percentage of jasmine plant in the two seasons of this study. In addition, data in the same Table revealed that leaf total carbohydrates percentage increased by the used all rates of chemical fertilization, with superiority for $6 \mathrm{~g} /$ pot-fertilized plants which scored 20.70 and $18.65 \%$ in the first and second seasons, respectively. As for the interaction effect between BA and chemical fertilization, data in Table, 6 cleared that sprayed jasmine plants with BA at $60 \mathrm{ppm}$ and enriched with chemical fertilization at 6 $\mathrm{g} /$ pot is being the most promising one for producing the greatest values as it scored 21.90 and $19.80 \%$ in the first and second seasons, respectively.

\section{Leaf nitrogen \%:}

Data in Table (6) indicated that using $\mathrm{BA}$ at the high concentration exhibited to be the most promising one for detecting the highest leaves nitrogen percentage in the two seasons. Also, all tested applications of chemical fertilization increased the values of this parameter, especially using the highest rate $(6 \mathrm{~g} / \mathrm{pot})$ as it recorded 1.65 and $1.68 \%$, when compared with un-fertilized plants in the first and second seasons, respectively. As for the interaction effect between BA and chemical fertilization, data presented in Table (6) showed that all resulted combinations between BA concentration and chemical fertilization succeeded in increasing the values of this parameter, with superiority for the combination of chemical fertilization at $6 \mathrm{~g} /$ pot in both seasons. However, the highest leaf nitrogen percentage (1.81 and 1.92\%) was recorded by the plants treated with benzyladenine at the high concentration and fertilized with chemical fertilization at $6 \mathrm{~g} / \mathrm{pot}$ in the two seasons of this experiment.

\section{Leaf phosphorus \%:}

Data outlined in Table (7) reported that the richest leaf phosphorus percentage was scored by using the high concentration of BA as it scored 0.265 and $0.262 \%$ in the first and second seasons, respectively. Moreover, all tested rates of chemical fertilization increased this character, especially the high level $(0.255$ and $0.251 \%)$ when compared with un-fertilized plants in the two seasons. Referring to the interaction effect between 
Table 6. Effect of benzyladenine (BA) and fertilization treatments on total carbohydrates (\%) and nitrogen percentage of Jasminum sambac during 2017 and 2018 seasons.

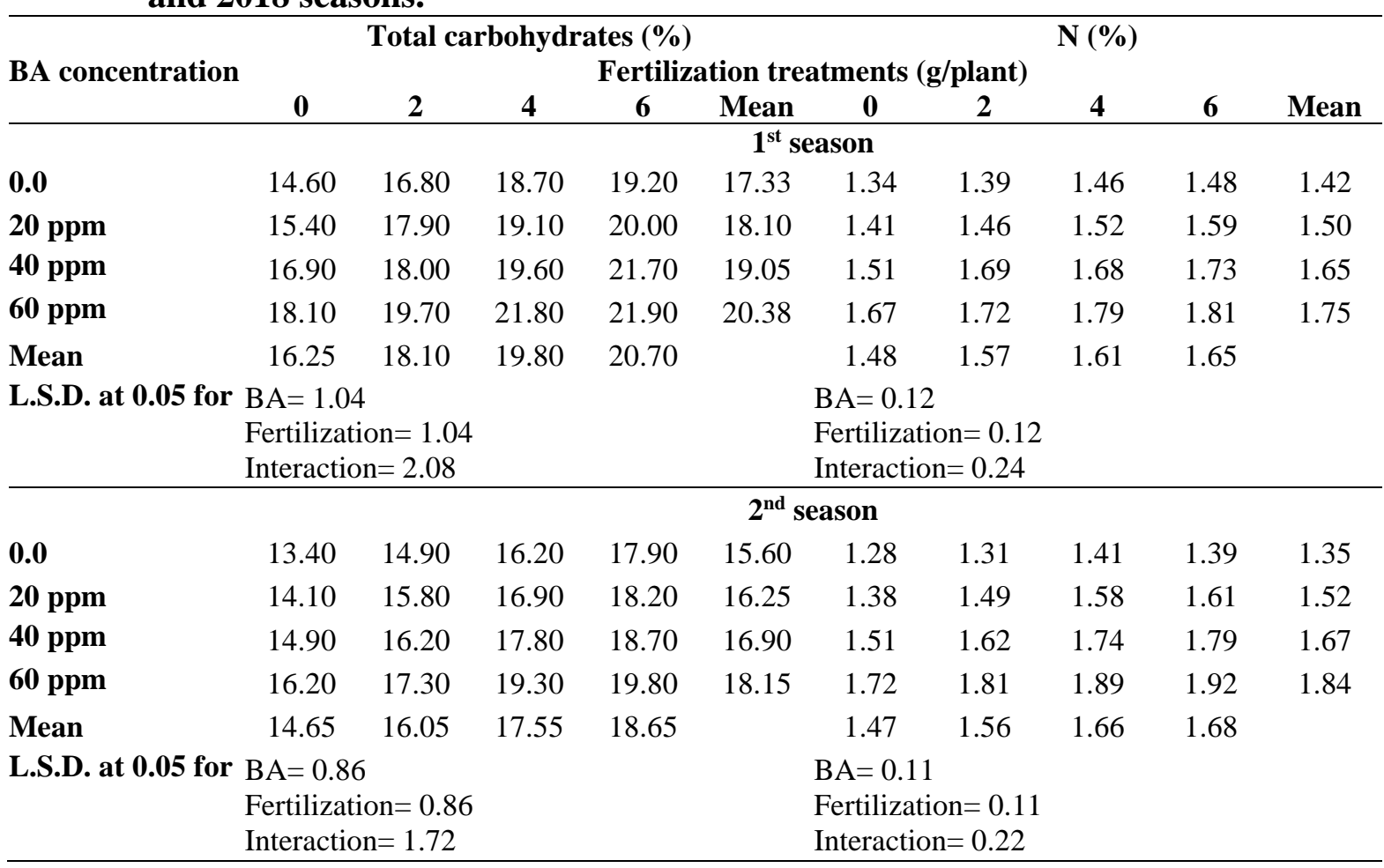

Table 7. Effect of benzyladenine (BA) and fertilization treatments on $P$ and $K$ percentage of Jasminum sambac during 2017 and 2018 seasons.

\begin{tabular}{|c|c|c|c|c|c|c|c|c|c|c|}
\hline \multirow{3}{*}{ BA concentration } & \multicolumn{5}{|c|}{$\mathbf{P}(\%)$} & \multicolumn{5}{|c|}{ K (\%) } \\
\hline & \multicolumn{10}{|c|}{ Fertilization treatments (g/plant) } \\
\hline & $\mathbf{0}$ & 2 & 4 & 6 & Mean & $\mathbf{0}$ & 2 & 4 & 6 & Mean \\
\hline & \multicolumn{10}{|c|}{$1^{\text {st }}$ season } \\
\hline 0.0 & 0.214 & 0.226 & 0.231 & 0.239 & 0.228 & 1.12 & 1.19 & 1.28 & 1.31 & 1.23 \\
\hline 20 ppm & 0.228 & 0.237 & 0.240 & 0.246 & 0.238 & 1.24 & 1.31 & 1.39 & 1.42 & 1.34 \\
\hline $40 \mathrm{ppm}$ & 0.241 & 0.249 & 0.258 & 0.264 & 0.253 & 1.36 & 1.42 & 1.56 & 1.59 & 1.48 \\
\hline 60 ppm & 0.251 & 0.263 & 0.274 & 0.270 & 0.265 & 1.45 & 1.5 & 1.63 & 1.68 & 1.57 \\
\hline Mean & 0.234 & 0.244 & 0.251 & 0.255 & & 1.29 & 1.36 & 1.47 & 1.50 & \\
\hline \multirow{3}{*}{\multicolumn{6}{|c|}{$\begin{aligned} & \text { L.S.D. at } 0.05 \text { for } B A=0.013 \\
& \text { Fertilization }=0.013 \\
& \text { Interaction }=0.026\end{aligned}$}} & & & & \\
\hline & & & & & & \multirow{2}{*}{\multicolumn{5}{|c|}{$\begin{array}{l}\text { Fertilization }=0.14 \\
\text { Interaction }=0.28\end{array}$}} \\
\hline & & & & & & & & & & \\
\hline & \multicolumn{10}{|c|}{$2^{\text {nd }}$ season } \\
\hline 0.0 & 0.204 & 0.216 & 0.224 & 0.228 & 0.218 & 1.17 & 1.21 & 1.29 & 1.34 & 1.25 \\
\hline 20 ppm & 0.219 & 0.232 & 0.241 & 0.243 & 0.234 & 1.21 & 1.32 & 1.38 & 1.41 & 1.33 \\
\hline $40 \mathrm{ppm}$ & 0.238 & 0.246 & 0.257 & 0.261 & 0.251 & 1.37 & 1.46 & 1.52 & 1.54 & 1.47 \\
\hline $60 \mathrm{ppm}$ & 0.247 & 0.259 & 0.268 & 0.272 & 0.262 & 1.42 & 1.51 & 1.62 & 1.65 & 1.55 \\
\hline Mean & 0.227 & 0.238 & 0.248 & 0.251 & & 1.29 & 1.38 & 1.45 & 1.49 & \\
\hline \multirow{3}{*}{ L.S.D. at 0.05 for } & $\mathrm{BA}=0.0$ & & & & & $B A=0$. & & & & \\
\hline & \multirow{2}{*}{\multicolumn{5}{|c|}{ Fertilization $=0.024$}} & \multirow{2}{*}{\multicolumn{5}{|c|}{$\begin{array}{l}\text { Fertilization }=0.12 \\
\text { Interaction }=0.24\end{array}$}} \\
\hline & & & & & & & & & & \\
\hline
\end{tabular}


BA and chemical fertilization, data in the same Table declared that all resulted interactions increased leaf phosphorus percentage in both seasons. However, the highest leaf phosphorus percentage $(0.270$ and $0.272 \%$ ) was registered by those received $\mathrm{BA}$ at the high concentration and fertilized with chemical fertilization at 6 $\mathrm{g} /$ pot in the two seasons.

\section{Leaf potassium \%:}

Data presented in Table (7) revealed that BA at the high concentration was more effective in increasing leaf potassium percentage of jasmine plant in the two seasons of this study. In addition, data in the same Table showed that leaf potassium percentage increased by all used rates of chemical fertilization, with superiority for 6 g/pot-fertilized plants which gave 1.50 and $1.49 \%$ in the first and second seasons, respectively. As for the interaction effect between BA and chemical fertilization, data presented in Table (7) cleared that sprayed jasmine plants with BA at the high concentration and enriched with chemical fertilization at $6 \mathrm{~g} / \mathrm{pot}$ is being the most effective one for producing the highest values as it scored 1.68 and $1.65 \%$ in the first and second seasons, respectively.

The aforementioned results of BA concerning chemical constituents are in conformity with those reported by Runkova (1985) on Dhalia pinnata, Auda (1992) on Hippeastrum vittatum, Maximoos (1993) on Gerbera jamesonii, El-Malt et al. (2006) on Hippeastrum vittatum and Youssef and Ismaeil (2009) on Clivia miniata.

However, the abovementioned results of chemical fertilization are in harmony with those attained by Hunmili and Paswan (2003) on gerbera, El-Malt et al. (2006) on Hippeastrum vittatum, Youssef and Gomaa (2007) on Iris tingitana, Abou El-Ella (2007) on Acanthus mollis, Kolodziej (2007) on goldenrod, Biswas and Parya (2008) on Solidago canadensis, Nath et al. (2008) on Peperomia, El-Naggar and El-Nasharty (2009) on Hippeastrum vittatum, Hussein
(2009) on Cryptostegia grandiflora and Abd El-All (2011) on Aspidistra elatior..

The obtained results might be due to the role of benzyladenine on promoting protein synthesis, increasing cell division, enlargement and chlorophyll synthesis (Cheema and Sharma, 1982). Moreover, these results might be explained according to the role of kinetin on promoting proteins, soluble and non-soluble sugars synthesis, or may be due to the ability of benzyladenine for making the treated area to act as a sink in which nutrients from other parts of the plant are drawn (Salisbury and Ross, 1974).

In conclusion, in order to produce good quality Jasminum sambac plants with more flowers, it is preferable to spray the plants with benzyladenine at $60 \mathrm{ppm}$ four times supplemented with mineral fertilization at 6 g/plant ten times a year.

\section{REFERENCES}

Abd Al Lateef, S. and Hade, S. (2018). The effect of foliar applications with gibberellic acid and benzyladenin on vegetative and floral growth of pansy plant (Viola tricolor). Journal of Agriculture and Veterinary Science, 11(3):12-17.

Abd El-All, S.G. (2011). Response of Castiron Plant (Aspidistra elatior Blume) to Foliar Nutrition with Greenzit and GA3. M.Sc. Thesis, Fac. Agric., Benha Univ., Egypt, 300 p.

Abou El-Ella, E.M. (2007). Physiological Studies on Acanthus mollis Plant. M.Sc., Thesis, Fac. Agric., Benha Univ., Egypt, $97 \mathrm{p}$.

Auda, M.S. (1992). Physiological Studies on Amaryllis Bulbs. Ph.D. Thesis, Fac. Agric., Ain Shams Univ., Egypt, 209 p.

Biswas, J. and Parya, C. (2008). Studies on influence of nitrogen, phosphorus and potassium on growth and flowering of golden rod (Solidago canadensis L.). Orissa Journal of Horticulture; 36(2):146-148. 
Brickell, C. (1997). The American Horticultural Society A-Z Encyclopedia of Garden Plants. DK Publishing, Inc., New York, USA, 1092 p.

Brown, J.D. and Lilleland, O. (1946). Rapid determination of potassium and sodium in plant material and soil extract by flame photometry. Proc. Amer. Soc., Hort., Sci., 48:341-346.

Carey, D.J.; Fair, B.A.; Buhler, W.; McCall, I. and Whipker, B.E. (2013). Growth control and flower promotion of Salvia with benzyladenine foliar sprays. Journal of Applied Horticulture (Lucknow), 15(2):87-89.

Cheema, G.S. and Sharma, D.P. (1982). In vitro propagation of apple rootstocks. Int. Hort. Congr. XXI., Hamburg, German Federal Republic, Int. Soc. Hort. Sci., 1:1035.

Currey, C.J. and Erwin, J.E. (2012). Foliar applications of plant growth regulators affect stem elongation and branching of 11 Kalanchoe species. HortTechnology, 22(3):338-344.

El-Malt, A.A.T.; El-Maadawy, E.E.; ElKhateeb, M.A. and El-Sadak, Z.H. (2006). Physiological studies on Hippeastrum vittatum L. plants, 2- Effect of NPK, CCC and BA on growth, bulblet production and flowering. Egypt. J. of Appl. Sci., 6B:724-742.

El-Naggar, A.H. and El-Nasharty, A.B. (2009). Effect of growing media and mineral fertilization on growth, flowering, bulbs productivity and chemical constituents of Hippeastrum vittatum, Herb. American-Eurasian J. Agric. \& Environ. Sci., 6(3):360-371.

Heneidy, S.Z. (2010). Plant Atlas: The Botanic Garden of Faculty of Science, Alexandria University. Mocchaa ElMaaref, Alex., Egypt, 632 p.

Herbert, D.; Phipps, P.J. and Strange, R.E. (1971). Determination of total carbohydrates, Methods in Microbiology, 5(8):290-344.
Hunmili, T. and Paswan, L. (2003). Effect of NPK on growth and flowering of gerbera. J. Ornamental Hort. (New Series), 6(1): 71-72.

Hussein, M.M. (2009). Effect of gibberellic acid and chemical fertilizers on growth and chemical composition of Cryptostegia grandiflora, r. br. plants. Mansoura Journal of Agricultural Science, 34(2):1237-1251.

Kolodziej, B. (2007). The effect of NPK fertilization on goldenrod (Solidago virgrea L. subsp. virgrea) yield and quality parameters. Herba Polonica, 53(3):129-134.

Lambers, H.; Chapin III, F.S. and Pons, T. (2008). Plant Physiological Ecology, $2^{\text {nd }}$ ed. edition. Springer, New York, 605 p.

Marschner, H. (1997). Mineral Nutrition of Higher Plants, Second Printing. Academic Press INC. San Diego, 889 p.

Maximoos, S.L. (1993). Physiological and Hormonal Studies on the Growth and Flowering of Gerbera Plant. Ph.D. Thesis, Fac. Agric., Ain Shams Univ., Egypt, 260 p.

Mengel, K. and Kirkby, E.A. (1987). Principles of Plant Nutrition. International Potash Institute, Bern, Switzerland, $687 \mathrm{p}$.

Mostafa, G.A.A. (2018) Effect of Planting Media and Fertilization on Growth and Chemical Composition of Areca plant. M.Sc. Thesis, Fac. Agric., Benha Univ., Egypt, 106 p.

Nath, M.R.; Pal, A.K. and Biswas, J. (2008). Effect of inorganic fertilizers on growth and development of three shade loving ornamental foliage plants. Orissa Journal of Horticulture; 36(1):59-63.

Pregl, F. (1945). Quantitative organic micro analysis, $4^{\text {th }}$ ed. J. \& Achurnil, London. Regul., 4:111-122.

Rees, A.R. (1992). Ornamental Bulbs, Corms and Tubers. C.A.B. Inter., Wallingford, UK, 220 p. 
Runkova, L.V. (1985). Cytokinin's effect on some ornamental plants. ActaHorticulturae, 167:69-77.

Salisbury, F.B. and Ross, C.W. (1974). Plant Physiology, $2^{\text {nd }}$ ed. Publishing Inc. Belmont., California., 422 p.

Singh, T. and Bala, M. (2018). Effect of foliar spray of benzyl adenine, gibberellic acid and putrescine on post-harvest keeping quality of chrysanthemum. Agricultural Research Journal, 55(2):386-388.

Snedecor, G.W. and Cochran, W.G. (1989). Statistical Methods, $7^{\text {th }}$ ed. Iowa State Univ. Press., Ames Iowa, USA, 507 p.

Tandel, M.H.; Animasaun, D.A. and Ramar K. (2018). Growth and phytochemical composition of Adhatoda zeylanica in response to foliar application of growth hormones and urea. Journal of Soil Science and Plant Nutrition, 18(3):881892.

Trouge, E. and Meyer, A.H. (1939). Improvement in deiness calorimetric for phosphorus and arsenic. Ind. Eng. Chem. Anal. Ed., 1:136-139.
Youssef, A.A. (2004). Influence of foliar spray with brassinosteroid and benzyladenine on the growth, yield and chemical composition of Pelargonium graveolens L. plants. Annals of Agricultural Science (Cairo Univ.), 49(1):313-326.

Youssef, A.S.M. and Gomaa, A.O. (2007). Effect of some horticultural treatments on growth, flowering, bulb production and chemical composition of Iris tingitana cv. Wedgwood. Proc. of The Third Conf. of Sustain. Agric. and Develop., Fac. Agric., Fayoum Univ., Egypt, 12-14 Nov.

Youssef, A.S.M and Ismaeil, F.H.M. (2009). Response of Clivia miniata plant to light intensity and kinetin treatments. Annals of Agric. Sc., Moshtohor, 47(1):149-164.

Youssef, A.S.M. and Mady, M.A. (2013). Influence of light intensity and benzyladenine on growth performance of Aspidistra elatior Blume plant. Research Journal of Agriculture and Biological Sciences, 9(5):248-257.

$$
\begin{aligned}
& \text { تأثير البنزايل آدينين والتسميد الكيماوي على النمو، الإزهار والمحتوى الكيميائي لنبات القل } \\
& \text { إيمان مختار أبو الغيط*، أحمد سعيد محمد يوسف إبر ، يسري فحمد قهي سعودي*، طارق محمد نور الدين**، }
\end{aligned}
$$

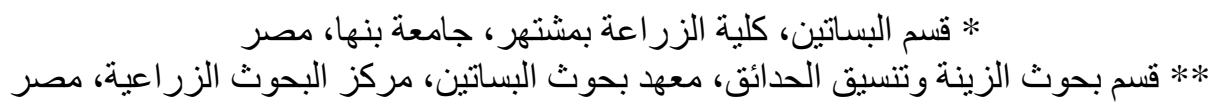

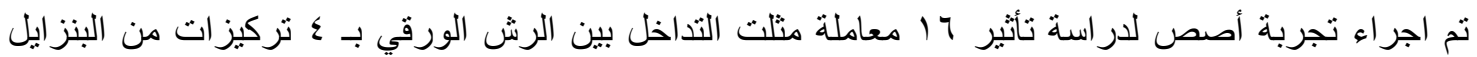

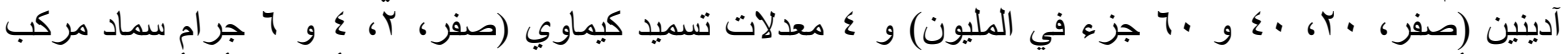

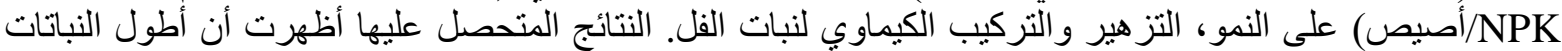

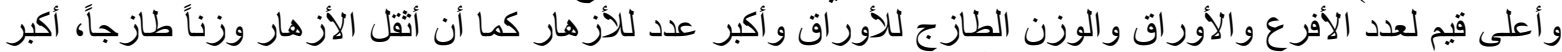

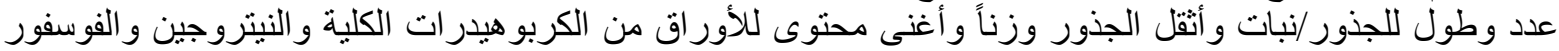

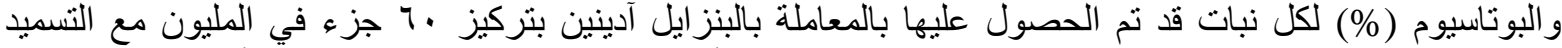

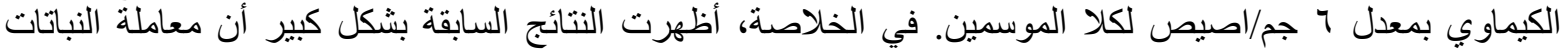

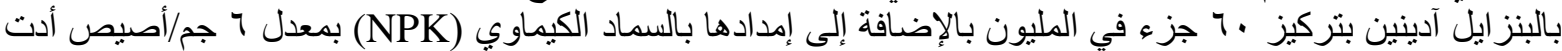

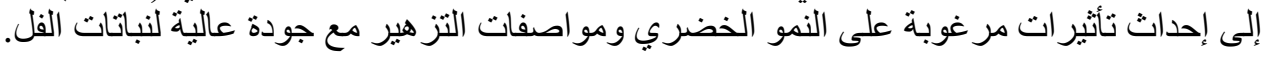

